\title{
PENGARUH KEBIJAKAN DEVIDEN, STRUKTUR AKTIVA DAN UKURAN PERUSAHAAN TERHADAP KEBIJAKAN UTANG (STUDI PADA PERUSAHAAN PROPERTY AND REAL ESTATE YANG TERDAFTAR DI BURSA EFEK INDONESIA TAHUN 2014 - 2017 )
}

\author{
Oleh: \\ Tagor Darius Sidauruk \\ Dwi Amelia Sari
}

Fakultas Ekonomi Jurusan Akuntansi

Universitas Satya Negara Indonesia

\section{ABSTRACT}

This study aimed to find out the effect of Dividend Policy, Asset Structure, and Firm Size, on the Debt Policy listed in Indonesia Stock Exchange. The period in this research was 4 years.This study used causal research, this research was conducted at property \& real estate company listed in Indonesia Stock Exchange from 2014 until 2017. The sample was selected using purposive sampling technique and the sample consisted of 9 companies.

The results of this study indicate that Dividend Policy has a positive and significance effect on the Debt Policy. The asset structure has not significant effect on the Debt Policy. Firm Size has a negative and significance effect on the Debt Policy. Simultaneously the Dividend Policy, Asset Structure, and Firm Size variables significantly influence Debt Policy.

Keywords: Debt Policy, Divident Policy, Asset Structure, and Firm Size.

\section{ABSTRAK}

Penelitian ini bertujuan untuk mengetahui pengaruh Kebijakan Dividen, Struktur Aktiva dan Ukuran Perusahaan terhadap Kebijakan Utang pada Perusahaan Property dan Real Estate yang terdaftar di Bursa Efek Indonesia. Periode yang digunakan dalam penelitian ini adalah 4 tahun. Desain penelitian ini adalah Penelitian Kausal. Populasi penelitian ini adalah perusahaan property and real estate yang sudah dan masih terdaftar di Bursa Efek Indonesia periode 2014 sampai 2017. Teknik pengambilan sampel menggunakan purposive sampling dan data penelitian diperoleh 9 perusahaan. Metode analisis data yang digunakan adalah regresi linear berganda.

Hasil dari penelitian ini menunjukan bahwa Kebijakan dividen berpengaruh signifikan terhadap kebijakan utang. Struktur aktiva tidak berpengaruh signifikan terhadap kebijakan utang. Ukuran Perusahaan berpengaruh negatif dan signifikan terhadap Kebijakan utang. Secara simultan variabel Kebijakan Dividen, Struktur aktiva, dan Ukuran Perusahaan berpengaruh signifikan terhadap Kebijakan utang. 
Kata kunci : Kebijakan Utang, Kebijakan Dividen, Struktur Aktiva dan Ukuran Perusahaan.

\section{PENDAHULUAN}

\subsection{Latar Belakang}

Pendanaan dalam sebuah perusahaan adalah salah satu komponen penting dalam keberlangsungan hidup suatu perusahaan, sehingga manajer keuangan mempunyai peran penting dalam pengambilan keputusan pendanaan. Kebijakan pendanaan perusahaan haruslah bertujuan untuk memaksimalkan kemakmuran perusahaan. Dalam hal ini kebijakan tersebut harus mempertimbangkan dan menganalisis sumber-sumber dana yang ekonomis guna membiayai kebutuhan dan investasi bagi perusahaan. Terdapat dua macam sumber pendanaan, yaitu modal sendiri dan utang. Selain mendapatkan dana dari modal sendiri yaitu dengan menggunakan laba ditahan, perusahaan juga dapat mendapatkan sumber dana dari kreditur dengan menggunakan kebijakan utang (Cindy, 2017).

Utang merupakan komponen yang tidak terpisahkan dari sebuah perusahaan. Tetapi pada umumnya utang digunakan untuk ekspansi perusahaan, mempunyai jumlah yang besar dan waktu yang lama (Rifai, 2015). Penggunaan utang oleh perusahaan juga dipengaruhi oleh kepercayaan dari pihak kreditur sebagai pemberi pinjaman dana (Andina, 2013).

Keputusan tentang kebijakan utang digunakan untuk memaksimalkan kemakmuran perusahaan dan juga untuk memaksimalkan keuntungan perusahaan. Tetapi apabila perusahaan menetapkan kebijakan untuk menggunakan sumber dana dari utang, berarti leverage keuangan perusahaan akan meningkat dan perusahaan akan menanggung biaya tetap berupa bunga yang harus dibayarkan. Menurut Jensen dan Meckling (1976) dalam Steven dan Lina (2011) dengan menggunakan utang maka perusahaan harus melakukan pembayaran periodik atas bunga. Membuat kebijakan utang perusahaan sangat tidak mudah karena dalam perusahaan terdapat banyak pihak yang memiliki kepentingan yang berbedabeda sehingga pembuatan keputusan tidak akan terlepas dari konflik keagenan yang terjadi dalam perusahaan. Konflik keagenan ini biasanya konflik kepentingan antara pemegang saham (stockholder), manajer (manager), dan kreditor (creditor) (Meylani, 2016).

Kebijakan dividen menentukan penempatan laba, yaitu laba pembayaran kepada pemegang saham dan menginvestasikan kembali dalam perusahaan. Laba ditahan (retained earning) merupakan salah satu dari sumber dana yang paling penting untuk membiayai pertumbuhan perusahaan tetapi deviden merupakan arus kas yang disisihkan untuk pemegang saham.

Hasil penelitian Ernayani (2015) menyatakan struktur aktiva berpengaruh terhadap kebijakan utang. Namun hasil penelitian tersebut bertentangan dengan hasil penelitian Puspitasari dan Manik (2016) yang menyatakan bahwa struktur aktiva tidak berpengaruh terhadap kebijakan utang.

Ukuran perusahaan digunakan untuk mengetahui besarnya jumlah alokasi untuk tiap komponen aset. Hasil penelitian Mahnaz Mahdavi et.al (2013) dan Nafisa (2016) menyatakan bahwa ukuran perusahaan memiliki pengaruh positif terhadap kebijakan utang. Namun hasil penelitian tersebut bertentangan dengan hasil penelitian Hidayat (2013) yang menyatakan bahwa ukuran perusahaan tidak berpengaruh terhadap kebijakan utang. 
Real estate merupakan salah satu bentuk aset. Perwujudan real estate tidak hanya berupa kepemilikan hunian mewah. Real estate adalah hak untuk memiliki sebidang tanah dan memanfaatkan apa saja yang ada di dalamnya, sebagai salah satu bentuk aset. Perusahaan real estate merupakan perusahaan yang menyediakan berbagai macam keperluan konsumen berupa rumah atau properti lainnya. Perusahaan property and real estate merupakan salah satu sektor industri yang terdaftar di Bursa Efek Indonesia (BEI).

Berdasarkan latarbelakang di atas, maka judul penelitian ini adalah "Pengaruh Kebijakan Deviden, Struktur Aktiva dan Ukuran Perusahaan Terhadap Kebijakan Utang (Studi Pada Perusahaan Property and Real Estate yang Terdaftar di Bursa Efek Indonesia Tahun 2014 - 2017)".

\subsection{Rumusan Masalah}

Berdasarkan latar belakang di atas, maka dalam penelitian ini permasalahan dirumuskan sebagai berikut :

1. Apakah kebijakan deviden berpengaruh terhadap kebijakan utang?

2. Apakah struktur aktiva berpengaruh terhadap kebijakan utang?

3. Apakah ukuran perusahaan berpengaruh terhadap kebijakan utang?

4. Apakah kebijakan dividen, struktur aktiva, dan ukuran perusahaan berpengaruh terhadap kebijakan utang?

\subsection{Tujuan Penelitian}

1. Untuk mengetahui pengaruh kebijakan deviden terhadap kebijakan utang.

2. Untuk mengetahui pengaruh struktur aktiva terhadap kebijakan utang.

3. Untuk mengetahui pengaruh ukuran perusahaan terhadap kebijakan utang.

4. Untuk mengetahui pengaruh kebijakan dividen, struktur aktiva dan ukuran perusahaan terhadap kebijakan utang.

\section{LANDASAN TEORI}

\subsection{Kebijakan Utang}

Utang (Liabilitas) merupakan kewajiban entitas masa kini yang timbul dari peristiwa masa lalu, penyelesaiannya diharapkan mengakibatkan arus keluar dari sumber daya entitas yang mengandung manfaat ekonomi (Hans Kartikahadi, dkk. 2016). Menurut Hans Kartikahadi, dkk. 2016, utang terdiri atas utang jangka pendek dan utang jangka panjang. Utang jangka pendek merupakan utang yang memiliki waktu satu tahun dalam pelunasannya. Jenis-jenis utang jangka pendek terdiri atas: (1) utang dagang, (2) utang wesel, (3) penghasilan yang ditangguhkan (deferred revenue). (4) kewajiban yang harus dipenuhi (accrual payable). (5) utang gaji. Utang jangka panjang merupakan kewajiban yang pelunasannya lebih dari satu periode akuntansi. Utang jangka panjang digunakan untuk menunjukkan utang-utang yang pelunasannya dilakukan dalam waktu lebih dari satu tahun atau akan dilunasi dari sumber-sumber yang bukan dari kelompok aktiva lancar. Utang jangka panjang ini biasanya dalam jumlah nominal yang besar. Adapun yang termasuk dalam kategori utang jangka panjang adalah sebagai berikut: (1) Pinjaman Obligasi. (2) Pinjaman Hipotik.

Kebijakan utang merupakan keputusan perusahaan yang diambil manajemen untuk menentukan besarnya utang dalam sumber pendanaannya yang digunakan untuk membiayai kegiatan operasional perusahaan. Kebijakan utang adalah segala jenis utang yang dibuat atau 
diciptakan oleh perusahaan, baik utang lancar maupun utang jangka panjang. Kebijakan utang dalam perusahaan merupakan kebijakan yang berkaitan dengan struktur modal perusahaan.

Ada beberapa teori tentang kebijakan utang, yaitu: (a) Trade of Theory: merupakan keputusan perusahaan dalam menggunakan utang berdasarkan pada keseimbangan antara penghematan pajak dan biaya kesulitan keuangan. (b) Pecking Order Theory: menyatakan bahwa manajer lebih menyukai pendanaan internal daripada pendanaan eksternal. (c) Signaling Theory: menyatakan bahwa perusahaan yang mampu mengahasilkan keuntungan cenderung meningkatkan utangnya karena tambahan bunga yang dibayarkan akan diimbangi dengan laba sebelum pajak.

\subsection{Kebijakan Dividen}

Dividen merupakan suatu pembagian laba dari suatu usaha yang diberikan kepada pemegang saham dimana laba tersebut dapat berupa dividen tunai atau dividen saham yang dapat memaksimumkan nilai perusahaan disamping keputusan investasi dan struktur modal.

Menurut Stice dan Skousen (2009) jenis dividen yang dapat dibagikan oleh perusahaan kepada pemegang sahamnya sebagai berikut : (a) Dividen tunai: yaitu bagian laba usaha yang dibagikan kepada pemegang saham dalam bentuk uang tunai. Bagi investor, dividen tunai tersebut menghasilkan kas dan dicatat sebagai pendapatan dividen (dividend revenue). (b) Dividen properti: distribusi kepada pemegang saham yang terutang dalam bentuk aset selain kas biasanya disebut dividen properti (property dividends). Dengan demikian perusahaan mentrasfer kepada pemegang saham kepemilikannya di perusahaan lain dalam efek tersebut. Dividen properti sering kali dilakukan di perusahaan tertutup. (c) Dividen saham: perusahaan dapat membagikan saham tambahan dari perusahaan itu sendiri kepada para pemegang saham sebagai dividen saham (stock dividends). Suatu dividen saham tidak mentransfer kas atau aset lain kepada para pemegang saham. (d) Dividen likuidasi: yaitu dividen yang ingin dibayarkan oleh perusahaan kepada pemegang saham dalam berbagai bentuknya, tetapi tidak didasarkan pada besarnya laba usaha atau saldo laba ditahan perusahaan.

Menurut Agus Sartono (2016) Kebijakan dividen adalah keputusan apakah laba yang diperoleh perusahaan akan dibagikan kepada pemegang saham sebagai dividen atau akan ditahan dalam bentuk laba ditahan guna pembiayaan investasi di masa mendatang. Apabila perusahaan memilih untuk membagikan laba sebagai dividen, maka akan mengurangi laba yang ditahan dan selanjutnya mengurangi total sumber dana intern atau internal finacing. Dengan demikian kebijakan dividen ini harus dianalisa dalam kaitannya dengan keputusan pembelanjaan atau penentuan struktur modal secara keseluruhan.

\subsection{Struktur Aktiva}

Perusahaan yang memiliki aset tetap jangka panjang yang tinggi, dikarenakan permintaan akan produk mereka tinggi. Hal tersebut akan mengakibatkan penggunaan utang jangka panjang. Menurut Bambang Riyanto (2011) Struktur aktiva terdiri dari aktiva lancar dan aktiva tetap. Aktiva lancar adalah aktiva yang habis dalam satu kali berputar dalam proses produksi, dan proses perputarannya dalam jangka waktu yang pendek (umumnya kurang dari satu tahun). Komponen aktiva lancar meliputi kas, bank, surat-surat berharga, piutang, persediaan, biaya dibayar dimuka, pendapatan yang masih harus diterima, pinjaman yang diberikan, dan aktiva lancar lainnya. Sedangkan aktiva tetap adalah aktiva yang tahan 
lama yang secara berangsur-angsur habis turut serta dalam peroses produksi. Aktiva tetap adalah kekayaan perusahaan yang memiliki wujud, mempunyai manfaat ekonomi lebih dari satu tahun dan diperoleh perusahaan untuk melaksanakan kegiatan perusahaan dan bukan untuk dijual.

Suatu perusahaan pada umumnya memiliki dua jenis aktiva yaitu aktiva lancar dan aktiva tetap. Kedua unsur aktiva ini akan membentuk struktur aktiva. Struktur aktiva juga disebut struktur aset akan tampak dalam sisi sebelah kiri neraca.

\subsection{Pengertian Ukuran Perusahaan}

Ukuran perusahaan dianggap mempengaruhi nilai perusahaan karena semakin besar ukuran perusahaan maka semakin mudah perusahaan memperoleh sumber pendanaan eksternal yang dapat dimanfaatkan untuk mencapai tujuan perusahaan. Perusahaan besar yang memiliki aset tetap yang besar pula, maka pemberi utang ataupun kreditur akan merasa mudah dalam memperoleh jaminan. Perusahaan yang besar (ukuran perusahaan yang besar) akan memiliki tingkat risiko bisnis yang rendah dibandingkan dengan perusahaan yang berukuran kecil, dengan jumlah aktiva tetap yang sedikit untuk jaminan. sehingga perusahaan berukuran besar akan mudah mendapatkan kepercayaan dari pihak kreditur. Ukuran perusahaan merupakan ukuran besar kecilnya sebuah perusahaan yang ditunjukan atau dinilai oleh total aset, total penjualan, jumlah laba, beban pajak dan lain-lain.

\section{Metodologi Penelitian}

\subsection{Waktu dan Tempat Penelitian}

Penelitian ini dilakukan selama 4 bulan yaitu dimulai bulan Maret sampai dengan Juni 2019. Dalam penelitian ini, peneliti memilih Perusahaan Subsektor Property dan Real Estate yang terdaftar di Bursa Efek Indonesia pada periode 2014-2017.

\subsection{Desain Penelitian}

Desain penelitian yang digunakan adalah penelitian kausal (causal research) yang merupakan penelitian untuk mengetahui pengaruh antara satu atau lebih variabel bebas terhadap variabel terikat.

\subsection{Variabel Penelitian}

Variabel yang digunakan dalam penelitian ini adalah sebagai berikut:

a. Variabel bebas atau independen yaitu kebijakan dividen (X1), struktur aktiva (X2), dan ukuran perusahaan (X3). Struktur aktiva menggambarkan kekayaan perusahaan yang dapat dijadikan jaminan dalam memperoleh utang. Struktur aktiva dihitung dengan cara sebagai berikut: Fixed Assets dibagi dengan total asset. Ukuran perusahaan diproksikan dengan Ln total aset.

b. Variabel terikat atau dependen yaitu kebijakan utang. Kebijakan utang diukur dengan menggunakan Debt to Equity Ratio, dihitung dengan rumus sebagai berikut: total debt dibagi dengan total equity.

\subsection{Jenis dan Sumber Data}

Penelitian ini menggunakan data sekunder, yaitu data yang diperoleh dari pihak lain atau data yang telah tersedia. Data sekunder dikumpulkan, dicatat dan diolah sendiri data yang sudah tersedia. Data tersebut diperoleh dari website Bursa Efek Indonesia (www.idx.co.id). 


\subsection{Populasi dan Sampel}

Populasi yang digunakan dalam penelitian ini adalah perusahaan sektor property dan real yang terdaftar di Bursa Efek Indonesia periode 2014-2017.

Teknik penarikan sampel yang digunakan dalam penelitian ini adalah teknik purposive sampling yaitu teknik pengambilan sampel yang didasarkan atas pertimbanganpertimbangan tertentu dari peneliti dengan kriteria sebagai berikut: (a) Perusahaan Subsektor Property and Real Estate yang terdaftar di BEI selama tahun 2014-2017. (b) Perusahaan Subsektor Property and Real Estate yang mendapatkan laba selama tahu 2045-2017. (c) Perusahaan Subsektor Property and Real Estate yang membagikan Dividen Kas selama tahun 2014-2017.

\subsection{Metode Analisis Data}

\subsubsection{Statistik Deskriptif}

Statistik deskriptif yaitu suatu teknik analisis data yang berusaha menjelaskan atau menggambarkan berbagai karakteristik data. Program yang digunakan untuk mengolah data adalah Statistical Product and Service Solution versi 22.00.

\subsubsection{Uji Asumsi Klasik}

\section{a. Uji Normalitas}

Model regresi yang baik adalah memiliki distribusi data normal atau mendekati normal. Normalitas dapat dideteksi dengan menggunakan uji statistik, yaitu KolmogorovSmirnov Test (Imam Ghozali, 2016). Adapun kriteria pengujian adalah: (1) apabila nilai signifikan Kolmogorov-Smirnov Test adalah $<0.05$ maka data residual tidak berdistribusi normal, dan sebaliknya (2) apabila nilai signifikan Kolmogorov-Smirnov Test adalah $>0.05$ maka data residual berdistribusi normal.

\section{b. Uji Autokorelasi}

Model regresi yang baik seharusnya tidak menunjukkan autokorelasi. Untuk mendeteksi ada tidaknya autokorelasi, maka nilai DW (Durbin Watson) akan dibandingkan dengan tabel DW. Kriteria yang dipakai adalah sebagai berikut: (1) Jika d lebih kecil dari $\mathrm{dL}$ atau lebih besar dari (4-dL) maka hipotesis nol ditolak, yang berarti terdapat autokorelasi. (2) Jika d terletak antara dU dan (4-dU), maka hipotesis nol diterima, yang berarti tidak ada autokorelasi. (3) Jika d terletak antara dL dan dU atau dimana (4-dU) dan (4-dL), maka tidak menghasilkan kesimpulan yang pasti.

\section{c. Uji Multikolinieritas}

Model regresi yang baik seharusnya tidak terjadi korelasi diantara variabel independen (Imam Ghozali, 2016). Untuk mendeteksi ada tidaknya multikolinearitas dalam suatu persamaan regresi adalah sebagai berikut: nilai Tolerance yang rendah maka akan berakibat pada VIF yang tinggi, dan ini berarti terjadi multikolinearitas. Dan sebaliknya, persamaan regresi tidak terjadi multikolinieritas jika nilai Tolerance $>0.10$, dan besarnya $\mathrm{VIF}<10$.

\section{d. Uji Heteroskedastisitas}

Model regresi yang baik adalah tidak terjadi heteroskedastisitas. Menurut Imam Ghozali (2016) uji Heteroskedastisitas bertujuan untuk mengetahui apakah sebuah model dalam regresi terjadi ketidaksamaan varians residual dari satu pengamatan ke pengamatan yang lain tetap, maka hal tersebut disebut homokedastisitas. Jika varians berbeda, disebut dengan heteroskedastisitas. Ada beberapa cara yang dapat dilakukan untuk melakukan uji heteroskedastisitas, diantaranya dengan grafik scatterplot. pengujian heteroskedastisitas dalam penelitian ini didasari oleh grafik Scatterplot. 


\subsubsection{Analisis Regresi Linier Berganda}

Analisis regresi linier berganda berguna untuk menganalisa hubungan linier antara 2 variabel independen atau lebih dengan 1 variabel dependen. Dalam uji regresi peneliti menggunakan regresi linier berganda untuk mencari pengaruh antar variabel dengan model sebagai berikut:

Keterangan :

$$
Y=a+\beta 1 X 1+\beta 2 X 2+\beta 3 X 3+e
$$

$\begin{array}{ll}\mathrm{Y} & =\text { Kebijakan utang } \\ \mathrm{a} & =\text { Konstanta } \\ \beta 1 \beta 2 \beta 3 & =\text { Koefisien Regresi untuk X1, X2, dan X3 } \\ \mathrm{X} 1 & =\text { Kebijakan Dividen (DPR) } \\ \mathrm{X} 2 & =\text { Struktur Aktiva (SA) } \\ \mathrm{X} 3 & =\text { Ukuran perusahaan (SIZE) } \\ \mathrm{e} & =\text { Faktor lain ( Faktor Pengganggu) }\end{array}$

\subsubsection{Uji Hipotesis}

\section{a. Koefisien Determinasi (Uji $\mathbf{R}^{2}$ )}

Untuk menyatakan besar kecilnya sumbangan variabel $\mathrm{X}$ terhadap $\mathrm{Y}$ dapat ditentukan dengan koefisien determinasi. Pada koefisien determinasi $\left(\mathrm{R}^{2}\right)$ pada intinya mengukur seberapa jauh kemampuan model dalam menerangkan variasi variabel dependen. Nilai $\mathrm{r}^{2}$ adalah antara 0 dan $1\left(0<\mathrm{R}^{2}<1\right)$, dimana suatu regresi yang baik akan menghasilkan nilai $\mathrm{r}^{2}$ yang tinggi. Hal ini berarti bahwa keseluruhan variabel bebas secara bersama-sama mampu menerangkan variabel terikatnya. Sedangkan $\mathrm{r}^{2}$ yang kecil berarti kemampuan variabel-variabel dependen sangat terbatas (Ghozali, 2016).

\section{b. Uji statistik t (Uji Signifikan Parsial)}

Uji hipotesis dalam penelitian ini diuji menggunakan model regresi linier berganda. Uji statistik t pada dasarnya menunjukkan seberapa jauh pengaruh satu variabel independen secara individual dalam menerangkan variasi varibel dependen. Hipotesis nol (H0) yang hendak diuji adalah apakah suatu parameter sama dengan nol, atau $\mathrm{H}$ ) : bi $=0$. Hipotesis alternatifnya (HA) parameter suatu variabel tidak sama dengan nol, atau $\mathrm{HA}:$ ba $\neq 0$. Uji parsial ditunjukkan oleh tabel Coeficients dalam hasil output SPSS. Selanjutnya untuk mengetahui signifikan pengaruh atau hubungan antar variabel dapat dilakukan pengambilan keputusan dengan kriteria sebagai berikut: (1) jika probabilitas $>0.05$, maka H0 tidak dapat ditolak, jadi variance sama. (2) jika probabilitas $<0.05$, maka H0 ditolak, jadi variance berbeda.

\section{c. Uji statistik F (Uji Signifikan Simultan)}

Uji simultan ditunjukkan oleh tabel Anova. Uji statistik $\mathrm{F}$ menunjukkan apakah semua variabel independen yang dimasukkan dalam model mempunyai pengaruh secara bersama-sama terhadap variabel terikat. Hipotesis nol (H0) yang hendak diuji adalah apakah semua parameter dalam model sama dengan nol, atau $\mathrm{H} 0: \mathrm{b} 1=\mathrm{b} 2=\ldots=\mathrm{bk}=0$. Hipotesis alternatifnya adalah tidak semua parameter secara simultan sama dengan nol, atau HA : b1 $\neq$ $\mathrm{b} 2 \neq \ldots \neq \neq \mathrm{bk} \neq 0$. Menentukan tingkat signifikan $(\alpha)$ yaitu sebesar $5 \%$ dapat dilakukan dengan berdasarkan nilai probabilitas, dengan cara: (1) Jika probabilitas $>0.05$ maka H0 tidak dapat ditolak, jadi variance sama. (2) Jika probabiliitas $<0.05$ maka H0 ditolak, variabel independen secara simultan mempengaruhi variabel terikat. 


\section{Analisis Hasil dan Pembahasan}

\subsection{Statistik Deskriptif}

Pengolahan data ini menggunakan program Statistical Package for the Social Science (SPSS). Berdasarkan kriteria yang telah ditepkan dengan menggunakan metode purposive sampling maka perusahaan property and real estate yang terdaftar di bursa efek indonesia yang memenuhi persyaratan sebanyak 21 perusahaan. Periode penelitian yang digunakan adalah 4 tahun yaitu tahun 2014-2017 sehingga sampel penelitian ini berjumlah 84 sampel.

Sebelum data digunakan untuk diolah penulis melakukan screening data hal ini dilakukan untuk membuang data-data yang akan mengganggu hasil penelitian. Setelah dilakukan screening data, maka dapat diketahui terdapat data outlier pada penelitian. Agar tidak mengganggu pengujian dalam penelitian ini, maka data outlier peneliti dikeluarkan dari sampel. Jumlah data outlier ada sebanyak 48 perusahaan, sehingga terdapat 36 sampel perusahaan property and real estate yang memiliki data sesuai dengan kebutuhan penelitian.

a. Kebijakan Dividen. Kebijakan Dividen ditunjukkan oleh proksi DPR. besarnya DPR mempunyai nilai minimum sebesar 0,08 , nilai maksimum sebesar 2,41 , nilai rata-rata (mean) sebesar 0,9765, dan standar deviasi sebesar 0,68614. Kebijakan Hutang tertinggi terjadi pada PT Alam Sutera Realty Tbk. sebesar 2,41138 sedangkan Kebijakan Hutang terendah terjadi pada PT Lippo Karawaci Tbk. sebesar 0,07911.

b. Struktur Aktiva. Struktur Aktiva ditunjukkan oleh proksi SA. Besarnya SA mempunyai nilai minimum sebesar 0,00 , nilai maksimum sebesar 0,90 , nilai rata-rata (mean) sebesar 0,1427, dan standar deviasi sebesar 0,23409. Struktur Aktiva tertinggi terjadi pada PT Roda Vivatex Tbk sebesar 0,79044. Sedangkan Struktur Aktiva terendah terjadi pada PT Jaya Real Property Tbk. sebesar 0,00001.

c. Ukuran Perusahaan. Ukuran Perusahaan ditunjukkan oleh proksi SIZE. Hasil Uji Statistik Deskriptif, menunjukkan bahwa besarnya SIZE mempunyai nilai minimum sebesar 22,31, nilai maksimum sebesar 31,46, nilai rata-rata (mean) sebesar 26,9971, dan standar deviasi sebesar 3,46. Ukuran Perusahaan tertinggi terjadi pada PT Bumi Serpong Damai Tbk. sebesar 31,45860, sedangkan Ukuran Perusahaan terendah terjadi pada PT Metropolitan Land Tbk.sebesar 22,30715.

d. Kebijakan Utang. Kebijakan utang ditunjukan oleh proksi DER. Berdasarkan pengujian yang dilakukan, besarnya Kebijakan utang mempunyai nilai minimum sebesar 0,00 , nilai maksimum sebesar 1,71, nilai rata-rata (mean) sebesar 0,7785, dan standar deviasi sebesar 0,45760. Kebijakan utang tertinggi terjadi pada PT Alam Sutera Realty Tbk. sebesar 1,70694 sedangkan Kebijakan utang terendah terjadi pada PT Jaya Real Property Tbk. sebesar 0,00058.

\subsection{Uji Asumsi Klasik}

Hipotesis dalam penelitian ini diuji dengan menggunakan teknik analisis regresi linier berganda. Dalam analisis regresi linier berganda harus memenuhi beberapa pengujian asumsi klasik. Uji asumsi klasik yang dilakukan dalam penelitian ini meliputi uji normalitas, uji kolmogorov-smirnov, uji multikolinieritas, uji autokolerasi, dan uji heteroskedastisitas. Berikut ini adalah uji asumsi klasik.

\section{Uji Normalitas}

Normalitas dapat diketahui dengan melihat tabel One-Sample Kolmogorov-Smirnov Test pada kolom Asymp.Sig (2-tailed) yaitu jika $p$ value (sig) > 0.05 maka dapat disimpulkan bahwa data yang diambil dari populasi berdistribusi normal. Berdasarkan hasil 
output SPSS, diperoleh hasil Asymp.Sig. (2-tailed) untuk variabel kebijakan dividen (X1), struktur aktiva (X2), ukuran perusahaan (X3), dan kebijakan utang (Y) adalah sebesar 0,082 $>0.05$. Karena Asymp. Sig $>$ dari 0.05, maka dapat disimpulkan bahwa data yang diambil dari populasi berdistribusi normal.

\section{Uji Multikolinearitas}

Untuk mendeteksi ada atau tidaknya multikolinearitas dalam suatu persamaan regresi adalah dengan melihat nilai Tolerance dan VIF pada tabel coefficients. Berdasarkan pengolahan data yang dilakukan, diperoleh hasil sebagai berikut: (a) variabel kebijakan dividen (X1) diperoleh nilai Tolerance $0,909>0,10$ dan nilai VIF $1,100<10$. (b) variabel struktur aktiva (X2) diperoleh nilai Tolerance $0,889>0,10$ dan nilai VIF $1,125<10$. (c) Variabel ukuran perusahaan (X3) diperoleh nilai Tolerance 0,974 $>0,10$ dan nilai VIF 1,027 $<10$. Berdasarkan data di atas dapat disimpulkan bahwa antar variabel independen tidak terjadi multikolinearitas.

\section{Uji Autokorelasi}

Model regresi yang baik seharusnya adalah regresi yang bebas dari autokorelasi. Metode pengujian yang sering digunakan untuk mengetahui autokorelasi adalah dengan uji Durbin-Watson (Uji DW). Berdasarkan pengujian data yang dilakukan diperoleh nilai Durbin Watson yang dihasilkan dari model regresi adalah 1,900. Karena nilai Durbin Watson 2,378 terletak di antara dU (1,6539) dan 4- dU (2,3461). Karena 1,6539<2,378< 2,3461 sehingga disimpulkan bahwa tidak terjadi autokorelasi.

\section{Uji Heteroskedastisitas}

Uji Heterokedastisitas bertujuan untuk menguji apakah dalam model regresi terjadi ketidaksamaan variance dari residual satu pengamatan ke pengamatan yang lain. Jika variance dari residual satu pengamatan ke pengamatan yang lain tetap, maka disebut homokedastisitas dan jika berbeda disebut heterokedastisitas (Imam Ghozali, 2011). Maka pengujian heteroskedastisitas dalam penelitian ini didasari oleh grafik Scatterplot. Berdasarkan pengujic

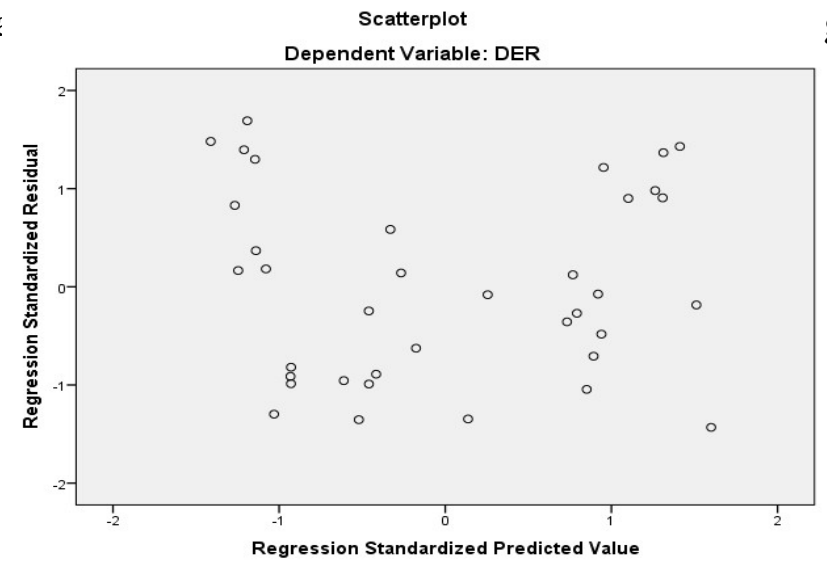
gai berikut :

\section{Gambar Analisis Grafik Scatterplot}

Sumber : Hasil Output SPSS 22, Data yang diolah, 2019.

Berdasarkan grafik scatterplot terlihat titik menyebar secara acak, tidak membentuk sebuah pola tertentu yang jelas atau teratur, serta titik tersebar di atas dan di bawah angka 0 pada sumbu Y. Dengan demikian dapat dikatakan bahwa tidak terjadi gejala heteroskedastisitas pada model regresi. 


\subsection{Analisis Regresi Linier Berganda}

Berikut ini adalah tabel hasil analisis regresi linier berganda dengan bantuan SPSS. Berdasarkan tabel di bawah ini, maka dapat dibuat persamaan regresi linier berganda sebagai berikut :

$\mathrm{Y}=1,953+0,250 \mathrm{X} 1+0,133 \mathrm{X} 2-0,052 \times 3+\mathrm{e}$

Tabel analisis regresi linier berganda

\begin{tabular}{|c|c|c|c|c|c|}
\hline \multirow[b]{2}{*}{ Model } & \multicolumn{2}{|c|}{$\begin{array}{c}\text { Unstandardized } \\
\text { Coefficients }\end{array}$} & \multirow{2}{*}{$\begin{array}{c}\text { Standardized } \\
\text { Coefficients } \\
\text { Beta }\end{array}$} & \multirow[b]{2}{*}{$\mathrm{t}$} & \multirow[b]{2}{*}{ Sig. } \\
\hline & $\mathrm{B}$ & Std. Error & & & \\
\hline 1 (Constant) & 1,953 & ,698 & & 2,797 & ,009 \\
\hline DPR & ,250 & , 107 & ,376 & 2,326 & , 027 \\
\hline SA &, 133 & ,318 &, 068 & ,419 & ,678 \\
\hline SIZE &,- 052 & 025 &,- 322 & $-2,066$ & 047 \\
\hline
\end{tabular}

a. Dependent Variable: DER

Sumber : Data dari Output SPSS

Dari persamaan tersebut bisa diambil kesimpulan sebagai berikut:

1. Konstanta sebesar 1,953 menunjukan bahwa apabila tidak ada variable independent (DPR, SA, dan DER) maka Kebijakan utang sebesar 1,953 atau sebesar Rp 1,953

2. Koefisien regresi Kebijakan Dividen $(\mathrm{X} 1)=0,250$ menunjukan bahwa setiap penambahan Kebijakan Dividen sebesar 1 dengan asumsi variable lainnnya dianggap konstan, maka akan menaikan tingkat kebijakan utang sebesar 0,250 atau sebesar 25\%,-

3. Koefisien regresi Struktur Aktiva $(\mathrm{X} 2)=0,133$ menunjukan bahwa setiap penambahan Struktur Aktiva sebesar 1 dengan asumsi variable lainnnya dianggap konstan, maka akan menaikan tingkat kebijakan utang sebesar 0,133 atau sebesar 13,3\%.

4. Koefisien regresi Ukuran Perusahaan $(X 3)=-0,052$ menunjukan bahwa setiap penambahan Ukuran Perusahaan sebesar 1 dengan asumsi variabel lainnnya dianggap konstan, maka akan menurunkan tingkat kebijakan utang sebesar -0,052 atau sebesar $5,2 \%$.

\subsection{Uji Hipotesis}

\section{Koefisien determinasi}

Koefisien determinasi $\left(\mathrm{R}^{2}\right)$ digunakan untuk mengukur seberapa jauh kemampuan model dapat menjelaskan variasi variabel dependen. Nilai $\mathrm{R}^{2}$ yang kecil berarti kecil juga kemampuan variabel-variabel independen dalam menjelaskan variasi variabel dependen yang sangat terbatas. Koefisien determinasi adalah kuadrat dari nilai korelasi pada tabel Model Summary Output SPSS yang dapat dihasilkan sebagai berikut:

\begin{tabular}{|l|c|r|r|c|}
\hline Model & $\mathrm{R}$ & $\mathrm{R}$ Square & $\begin{array}{c}\text { Adjusted R } \\
\text { Square }\end{array}$ & $\begin{array}{c}\text { Std. Error of the } \\
\text { Estimate }\end{array}$ \\
\hline 1 &, $491^{\mathrm{a}}$ &, 241 &, 170 &, 41562 \\
\hline
\end{tabular}

a. Predictors: (Constant), SIZE, DPR, SA

b. Dependent Variable: DER

Berdasarkan tabel di atas diperoleh bahwa nilai koefisien determinasi ( $R$ Square) sebesar 0.241 atau sebesar $24,1 \%$. Hal ini berarti bahwa variabel kebijakan dividen, struktur aktiva dan ukuran perusahaan mampu menjelaskan variabel kebijakan utang sebesar 24,1\%, 
sedangkan sisanya $75,9 \%$ dipengaruhi oleh faktor-faktor lain yang tidak dimasukkan dalam model dalam penelitian ini.

\section{Uji statistik F (uji signifikan simultan)}

Uji statistik F menunjukkan apakah semua variabel independen yang dimasukkan dalam model mempunyai pengaruh secara bersama-sama terhadap variabel terikat. Pengujian dilakukan dengan tingkat signifikansi 0.05 atau $\alpha=5 \%$. Uji F dilihat dalam tabel ANOVA output SPSS dalam kolom sig, jika probabilitas $<0.05$ maka dapat dikatakan terdapat pengaruh secara bersama-sama variabel independen terhadap variabel dependen dan model regresi bisa dipakai untuk memprediksi variabel dependen, dan sebaliknya. Berikut ini adalah kriteria pengujian yang dilakukan:

a. Jika Sig $<0.05$, maka Ho ditolak dan Ha diterima.

b. Jika Sig $>0.05$, maka Ho diterima dan Ha ditolak.

\begin{tabular}{|ll|r|r|r|r|c|}
\hline \multicolumn{1}{|l|}{ Model } & Sum of Squares & Df & Mean Square & F & Sig. \\
\hline 1 & Regression & 1,757 & 3 &, 586 & 3,390 &, $030^{\mathrm{b}}$ \\
& Residual & 5,528 & 32 &, 173 & & \\
Total & 7,285 & 35 & & & \\
\hline
\end{tabular}

a. Dependent Variable: DER

b. Predictors: (Constant), SIZE, DPR, SA

Hasil Uji Anova atau F-test pada table 4.10 menunjukan F-hitung sebesar 5,101 dengan tingkat signifikansi 0,030 sedangkan $\mathrm{F}_{\text {table }}(\mathrm{F}=\mathrm{k}: \mathrm{n}-\mathrm{k}) \mathrm{F}=3 ; 33=0,091$. Diketahui bawah $\mathrm{F}_{\text {hitung }}>\mathrm{F}_{\text {tabel }}(3,390>0,091)$ dan tingkat signifikansi $0,030<0,05$ maka Ha diterima dan $\mathrm{H}_{\mathrm{o}}$ ditolak yang artinya bahwa Kebijakan Dividen, Struktur Aktiva dan Ukuran Perusahaan secara simultan berpengaruh signifikan terhadap Kebijakan utang.

\section{Uji statistik t (uji signifikan parsial)}

Uji t yaitu suatu uji untuk mengetahui signifikansi pengaruh variabel independen (kebijakan dividen, struktur aktiva, ukuran perusahaan) secara parsial menerangkan terhadap variabel dependen (kebijakan utang). Pengujian ini dinilai dengan tingkat signifikansi 0.05 atau $\alpha=5 \%$. Berikut ini adalah kriteria pengujian yang dilakukan:

1. Jika Nilai Sig $<0.05$, maka Ho ditolak dan Ha diterima.

2. Jika Nilai Sig $>0.05$, maka Ho diterima dan Ha ditolak.

Berdasarkan tabel analisis regresi linier berganda di atas, maka dapat dijelaskan mengenai pengaruh secara parsial masing-masing variabel independen sebagai berikut:

\section{a. Pengaruh kebijakan dividen terhadap kebijakan utang}

Dari pengujian statistik menunjukan bahwa $t_{\text {hitun }}>t_{\text {tabel }}$ yaitu 2,326 $>2,0369$ sedangkan nilai signifikan yang dihasilkan lebih kecil dari alpha $(\alpha)$, yakni 0,027<0,05. Hal ini berarti menunjukkan bahwa keputusan yang diambil adalah menerima Hipotesis alternative. Berarti secara parsial kebijakan dividen berpengaruh terhadap kebijakan utang.

Semakin besar dividen maka semakin kecil free cash flow perusahaan sehingga perusahaan membutuhkan tambahan sumber pendanaan melalui utang untuk membiayai investasi perusahaan, sehingga apabila jumlah dividen besar maka akan semakin besar pula utang perusahaan. Ketika sebagian besar keuntungan perusahaan dibagikan kepada pemegang saham sebagai dividen, maka kas yang tersedia untuk kebutuhan dana perusahaan dalam bentuk laba ditahan akan semakin menurun. Pecking Order Theory menyatakan 
bahwa dalam penggunaan utang, pertama kali perusahaan akan menggunakan laba ditahan, kemudian apabila tidak tercukupi maka akan digunakan pendanaan dengan utang.

Hasil penelitian ini mendukung penelitian yang dilakukan Irvan Riska fauzi (2017) dan Ari Hidayat Yulianto (2010), dimana kebijakan dividen berpengaruh positif terhadap kebijakan utang.

\section{b. Pengaruh struktur aktiva terhadap kebijakan utang}

Dari pengujian statistik menunjukan bahwa $t_{\text {hitun }} t_{\text {tabel }}$ yaitu $0,419<2,0369$ sedangkan nilai signifikan yang dihasilkan lebih besar dari alpha $(\alpha)$, yakni 0,678>0,05. Hal ini berarti menunjukkan bahwa keputusan yang diambil adalah menolak Hipotesis alternative. Berarti secara parsial struktur aktiva tidak berpengaruh terhadap kebijakan utang.

Hasil penelitian ini menjelaskan bahwa aktiva tetap tidak menjadi tolak ukur perusahaan dalam menentukan tingkat utang yang akan diperhitungkan oleh perusahaan. Dalam perusahaan property ini aktiva tetap tidak digunakan sebagai jaminan dalam menggunakan dana eksternal atau utang karena pada industri property ini, tanah dan bangunan yang dimiliki masuk kedalam klasifikasi aset lancar atau persediaan. Dari hasil penelitian ini menunjukkan adanya konsistensi dengan penelitian terdahulu yang dilakukan Meivita Manoppo, dkk (2018) dan Ni Kadek, dkk (2016) yang menyatakan bahwa Struktur aktiva tidak berpengaruh signifikan terhadap kebijakan utang karena masih rendahnya porsi aktiva tetap dan tingkat struktur aktiva yang dimiliki perusahaan property \& real estate dengan nilai rata-rata sebesar 0,0905 atau 9\% sehingga menyebabkan perusahaan sulit memperoleh pinjamaan karena aktiva tetap yang akan dijadikan jaminan bernilai tidak tinggi.

\section{c. Pengaruh ukuran perusahaan terhadap kebijakan utang}

Dari pengujian statistik menunjukan bahwa $t_{\text {hitun }}>t_{\text {tabel }}$ yaitu $-2,066>2,0369$ sedangkan nilai signifikan yang dihasilkan lebih kecil dari alpha $(\alpha)$, yakni 0,047<0,05. Hal ini berarti menunjukkan bahwa keputusan yang diambil adalah menolak Hipotesis alternative. Berarti secara parsial ukuran perusahaan berpengaruh negatif terhadap kebijakan utang.

Hasil penelitian ini menunjukkan adanya konsistensi dengan penelitian terdahulu yang dilakukan oleh Hari Kusrini (2012) yang menyatakan bahwa ukuran perusahaan terbukti berpengaruh negatif dan signifikan terhadap kebijakan utang atau semakin besar ukuran perusahaan maka semakin menurun kebijakan utang pada perusahaan property and real estate.

\section{Kesimpulan dan Saran}

\section{Kesimpulan}

Adapun kesimpulan dalam penelitian ini adalah sebagai berikut:

1. Kebijakan dividen berpengaruh positif dan signifikan terhadap kebijakan utang, sehingga Kebijakan dividen dapat digunakan untuk memprediksi kebijakan utang pada perusahaan subsektor property and real estate tahun 2014-2017.

2. Struktur Aktiva tidak berpengaruh terhadap kebijakan utang, sehingga struktur aktiva tidak dapat digunakan untuk memprediksi kebijakan utang pada perusahaan subsektor property and real estate tahun 2014-2017.

3. Ukuran Perusahaan berpengaruh negatif dan signifikan terhadap kebijakan utang. 
4. Secara simultan variabel Kebijakan Dividen, Struktur aktiva, dan Ukuran Perusahaan berpengaruh signifikan terhadap Kebijakan utang.

D. Saran

Berdasarkan kesimpulan diatas, maka peneliti mengajukan beberapa saran yaitu sebagai berikut

1. Para investor diharapkan dapat memperhatikan variabel independen kebijakan dividen, karena mempunyai pengaruh yang signifikan terhadap kebijakan utang.

2. Perusahaan sebaiknya menjaga keadaan struktur aset sehingga dapat meningkatkan harga saham dan berdampak pada kebijakan utang.

3. Peneliti selanjutnya diharapkan mampu menambah variabel independen yang lain yang berpengaruh terhadap kebijakan utang seperti risiko bisnis, likuiditas, dan tingkat suku bunga.

4. Peneliti selanjutnya perlu menggunakan objek penelitian yang lebih luas, tidak hanya menggunakan perusahaan Property And Real Estate, tetapi dapat menambah dengan perusahaan industri yang lainnya.

5. Peneliti selanjutnya diharapkan mampu menambah periode tahun penelitian.

\section{DAFTAR PUSTAKA}

Agus, R Sartono. 2010. Manajemen Teori dan Aplikasi. Edisi keempat. Yogyakarta. BPFE Universitas Gadjah Mada.

Andina, Zulfia. 2013. "Analisis Pengaruh Profitabilitas, Likuiditas, Pertumbuhan Penjualan, Pertumbuhan Perusahaan, dan Ukuran Perusahaan Terhadap Kebijakan Utang (Studi Kasus Pada Perusahaan Manufaktur Yang Terdaftar di BEI Periode 2008-2010)" Jurnal Bisnis dan Ekonomi.

Bambang Riyanto. 2011, “Dasar - Dasar Pembelanjaan Perusahaan” Edisi Keempat, Cetakan Ketujuh, Yogyakarta : YBPFE UGM.

Devi, Cindy Cinthia. 2016. "Faktor-Faktor yang Mempengaruhi Kebijakan Utang Perusahaan LQ45 yang Terdaftar di Bursa Efek Indonesia Periode 2014-2016” Skripsi. Fakultas Ekonomi dan Bisnis. Universitas Islam Negeri Syarif Hidayatullah Jakarta.

Erayani, R., Anam, H., dan Dwi, C. 2015. "Pengaruh Struktur Aset, Ukuran Perusahaan dan Pertumbuhan Perusahaan Terhadap Kebijakan Utang." (Studi pada Perusahaan Farmasi periode 2010-2014). Journal of Sustainable Competitive Advantage, 1- 14.

Fauzi, Irfan Rizky. 2017. Pengaruh Kepemilikan Manajerial, Ukuran Perusahaan, Kebijakan Dividen, dan Profitabilitas Terhadap Kebijakan Utang Pada Perusahaan Manufaktur yang Terdaftar di BEI Tahun 2012-2014. Skripsi Fakultas Ekonomi Universitas Negeri Yogyakarta. 